Article

\title{
Increasing the Efficiency of Sealing the Borehole in Terms of Spacer Pumping Time
}

\author{
Marcin Kremieniewski *(D), Miłosz Kędzierski (D) and Sławomir Błaż \\ Oil and Gas Institute-National Research Institute, 25A Lubicz Str., 31-503 Krakow, Poland; \\ kedzierski@inig.pl (M.K.); blaz@inig.pl (S.B.) \\ * Correspondence: marcin.kremieniewski@inig.pl
}

check for updates

Citation: Kremieniewski, M.; Kẹdzierski, M.; Błaż, S. Increasing the Efficiency of Sealing the Borehole in Terms of Spacer Pumping Time. Energies 2021, 14, 6702. https:// doi.org/10.3390/en14206702

Received: 2 September 2021

Accepted: 12 October 2021

Published: 15 October 2021

Publisher's Note: MDPI stays neutral with regard to jurisdictional claims in published maps and institutional affiliations.

Copyright: (c) 2021 by the authors. Licensee MDPI, Basel, Switzerland. This article is an open access article distributed under the terms and conditions of the Creative Commons Attribution (CC BY) license (https:/ / creativecommons.org/licenses/by/ $4.0 /)$.

\begin{abstract}
The tightness of a borehole is essential for its long-term durability. For this purpose, the column of the pipe is sealed with cement slurry. After contacting the slurry, mud in the borehole is removed. However, the slurry does not effectively remove the remaining drilling mud. Therefore, the annular space is cleaned with a wash. Effectively cleaning the borehole presents quite a problem, as many variables that affect the stability of the borehole need to be considered. The time of contact between the borehole and the wash is very important. On the one hand, insufficient contact time does not guarantee proper removal of the mud. On the other hand, a long contact time may destroy the wall of the borehole. To address these problems, studies were carried out to assess the effect of the wash contact time on annular space cleaning. When determining the time of washing, a compromise between effective cleaning and the stability of the borehole wall is required. In the research presented in this publication, the simplest wash was used, i.e., water. This choice was based on the objective of observing the influence of the wash time on cleaning, i.e., the preparation of the borehole for cementing. By using water, the physicochemical action of surfactants can be ignored. In order to capture changes in cleaning due to differences in contact time, a control test was performed using a pure sandstone core without mud. The effect of the wash contact time on the cleaning of the annular space was investigated by determining the adhesion of the cement sheath to the rock core. First, mud was formed on the core, and then it was removed. By comparing the obtained adhesion to the reference sample, the effectiveness of the deposit removal was determined. On the basis of this research, the optimal wash contact time was determined.
\end{abstract}

Keywords: drilling fluids; wash; mud cake; annular space; borehole cleaning; cementing; wash contact time

\section{Introduction}

To remove drilling fluid and prepare the annular space for the addition of cement slurry, a sequence of drilling fluids is pumped into the borehole. After drilling to the required depth, the drill string is removed from the borehole, and the mud circulation is interrupted. Subsequently, geophysical measurements are carried out, casing pipes are installed, and the mud cycle is repeated [1-4]. When the casing is placed in the bore after the rheological parameters of the mud have been adjusted, further drilling fluids are pumped into the borehole. The following process describes the preparation of the borehole for cementing. After conditioning the well, fluids are pumped into the borehole in the following order: cement slurry, spacer, and displacement fluid (usually drilling fluid). The wash should leave the surface of the pipe and the wall of the borehole moistened, which will improve the bonding of the cement slurry. The wash contact parameters are very important. If wash flow conditions are dense with a turbulent regime, the mud is more effectively removed. However, it is also important to use wash flow conditions that do not cause fractures in the formation, which can occur when the pumped fluid at the bottom of the borehole becomes excessively high due to a high delivery rate. Sufficient contact time between the wash and the annular space is necessary, as this allows 
the mud to be effectively removed [5-9]. Cleaning the borehole prior to cementing is essential for many reasons [10-12]. Effective removal of the mud cake from the annular space prior to cementing enables the required tightness to be obtained between the rock, the cement sheath, and the casing pipe [13-16]. Tight contacts limit gas release after cementing $[17,18]$. Achieving the required tightness of the borehole also enables longterm operations while preventing the corrosive environment from adversely affecting the pipe columns [19-21]. Borehole cleaning issues involve such factors as the rheology of drilling fluids, fluid mechanics, the mechanism of action of chemicals, surfactants, and the chemistry of cement during hydration [22,23]. Conducting research to improve borehole cleaning is essential because, despite recent progress in the development of techniques and technology for sealing pipe columns, some cementing treatments are still unsuccessful. Successful sealing of the borehole depends on the correct performance of cementing, but this is only one component of an effective borehole seal [24-26]. Experience shows that the quality and quantity of the remaining mud cake affect the effectiveness of sealing the pipe column [27-30]. Therefore, it is necessary to consider the borehole clearance in specific geological conditions and the washer composition. However, the composition and effect of the wash on the mud cake are only part of the problem. The second important factor is the wash contact conditions. Wash liquids have Newtonian characteristics, which enable the dispersal of mud. The low viscosity of the wash makes it possible to pump it in turbulent conditions, but it requires the use of higher delivery rates, which is a problem in weakly compact geological structures. Injecting the wash at high delivery rates can cause depressurization of the zone near the well. This should be borne in mind when establishing wash contact conditions. However, effective removal of the mud cake is possible with a suitable Reynolds number ( $R e>2300$ ). In some cases, mud cake residues will not be completely removed. Then, a second variable must be adjusted, which determines the effectiveness of mud cake removal. This second factor is the wash contact time $[25,27,28,31,32]$, which can be from 2 to $15 \mathrm{~min}$. The literature frequently reports values of 4,5 , or 8 min $[23,25,27,33-37]$. The optimal wash contact time depends on the delivery rate, mud cake removal characteristics, type of mud cake, borehole conditions, and other parameters. Therefore, the correct preparation of the borehole depends not only on the appropriate selection of the wash contact time but also on the optimal contact conditions and the chemical composition of the wash. This study shows borehole-like conditions with respect to deposit formation on the core surface and deposit removal. In previous studies, a deposit was produced on the core in a viscometer. Then, a core rotation was used and the liquid was under static conditions. However, in this paper other possibilities are presented. The cores are stationary as they are in the bore, while the liquid is in motion. The liquid flows from the bottom of the hole upwards as in the borehole. Thereby, a mud cake is produced and then, when washing is performed, the spacer removes the mud cake. Publications on borehole preparation for annular cleaning are available. However, as far as the precise consideration of the contact time of the washing liquid on the wall of the bore and the surface of casing pipes is concerned, the literature on such items is scarce. Therefore, it has been decided to fill this gap in the literature and conduct research to improve borehole sealing with respect to spacer contact time.

\section{Materials and Methods}

\subsection{Materials}

Tap water was used to remove the mud cake. The mud cake was prepared from polymer-potassium mud, the composition of which is given in Table 1.

A mud cake was formed on a core cut from heavy sandstone. The core was $25 \mathrm{~mm}$ in diameter and $60 \mathrm{~mm}$ in height. The average value of the compressive strength of the core was $8.5 \mathrm{MPa}$. The core had a uniform, non-cracked structure. 
Table 1. Composition of the drilling mud.

\begin{tabular}{cc}
\hline Ingredients & Concentration Percent by Weight \\
\hline Biocide & 0.2 \\
Xanthan gum & 0.3 \\
Carboxymethylcellulose & 2.5 \\
Partially hydrolyzed polyacrylamide & 0.2 \\
(polymeric clay hydration inhibitor) & 0.5 \\
$\mathrm{KCl}$ (potassium chloride as an ionic inhibitor) & \\
\hline
\end{tabular}

CEM I 42.5R Portland cement was used to create the cement slurry. It contained $2.66 \% \mathrm{SO}_{3}$ and $0.065 \% \mathrm{Cl}^{-}$. Means were used to adjust the parameters of the cement slurry. Plasticizer PSP 046 is a modified naphthalene lignosulfonate dispersant. Its bulk density is approximately $500 \pm 50 \mathrm{~kg} / \mathrm{m}^{3}$, and its $\mathrm{pH}$ is between 6.6 and 8.5 . A defoaming agent, which is a mixture of unsaturated fatty acid esters and refined hydrocarbons, was added to the cement slurry. An anti-filtration agent was included in the starter and setting accelerator. Latex, which is a dispersion of styrene-butadiene copolymer, was also used to seal the set cement. The sponge contained $10 \%$ microcement, which is characterized by grains up to $10 \mu \mathrm{m}$ and a specific surface area of approximately $1400 \mathrm{~m}^{2} / \mathrm{kg}$. Microcement reduces porosity and increases compressive strength. The percentages of materials used to prepare the cement slurry are summarized in Table 2 [28].

Table 2. Recipe and parameters of the cement slurry used in the adhesion test on the hardened cement-rock contact [27].

\begin{tabular}{cc}
\hline Ingredients & Percent by Mass of Cement \\
\hline Water-cement ratio & 0.45 \\
Plasticizer & 0.2 \\
Latex & 10.0 \\
Stabilizer & 1.0 \\
Defoaming agent & 0.5 \\
Anti-filtration agent & 0.2 \\
Setting accelerator & 4.0 \\
Microcement & 10.0 \\
Cement CEM I 42.5R & 100.0 \\
\hline
\end{tabular}

All components in percent by mass of cement.

\subsection{Preparation of the Cement Slurry}

A mud cake was formed on the rock cores to determine the effectiveness of borehole cleaning for different wash contact times. Then, the cores were washed and sealed with the cement slurry. The slurry is prepared as follows. The required amount of water is measured with a measuring cylinder. Water is poured into the mixer, which is then turned on and set to a speed of $1600 \mathrm{rpm}$. Cement slurry parameter-modifying agents are added and mixed for $10 \mathrm{~min}$. Then, fine-grained agents (microcement, microspheres, microsilica, and cement) are poured into the water with the other agents. The agents are mixed for another $20 \mathrm{~min}$. Mixing at low speed is similar to preparing slurry in borehole conditions.

\subsection{Experimental Procedures}

The properties of the cement paste were tested in accordance with the standard:

- PN-EN ISO 10426-2. Oil and gas industry. Cements and materials for cementing holes. Lot 2: Testing of drilling cements. In these tests, the following were measured: slurry density, filtration, and thickening time.

The adhesion test was carried out according to the standard:

- PN-EN 196-1: 2006 Cement testing methods. Strength marking. 
The research methodology was designed to determine the optimal wash contact time to improve the hole preparation method. The research was carried out in a drilling fluid flow simulator constructed for the needs of the tests (Figure 1) [35]. The liquid in the device flows in a closed circuit. The liquid flow rate was $11.2 \mathrm{~L} / \mathrm{min}$ in all tests. This value allows the contact of the liquid while maintaining the Reynolds number at over 2300. During the tests, the contact times were 4, 6, 8, and $10 \mathrm{~min}$. Cores cut from Ciężkowice sandstone were used for the tests. The core sample is Ciężkowice sandstone with a porosity of about $20 \%$. It is a quartz sandstone that was formed in the period from the Upper Paleocene to the Lower Eocene. It is sandstone, red-gray in color, very compact, with a loose grain skeleton. It has coarse-grained, deep-sea sediments. The permeability of the sandstone core is from 10 to $50 \mathrm{mD}$, and in some samples it ranges from 80 to $250 \mathrm{mD}$. The cores were cylindrical with a diameter of $0.025 \mathrm{~m}$ and a length of $0.06 \mathrm{~m}$ (Figure 2) $[27,28]$. The cores were placed in a tripod inside a PVC pipe (Figure 3) $[27,28]$. The drilling fluids flowed in the pipe. The device simulates the annular space of the borehole.

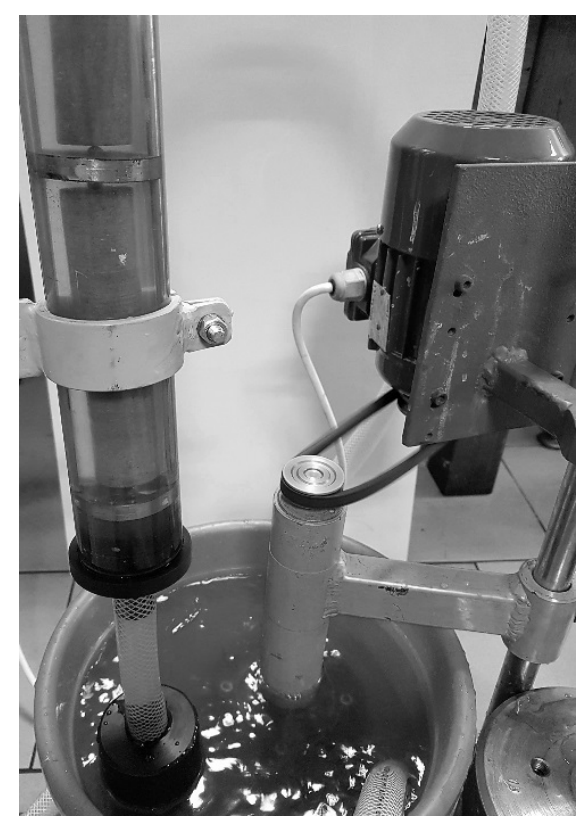

Figure 1. A photo of the drilling fluid flow simulator [27].

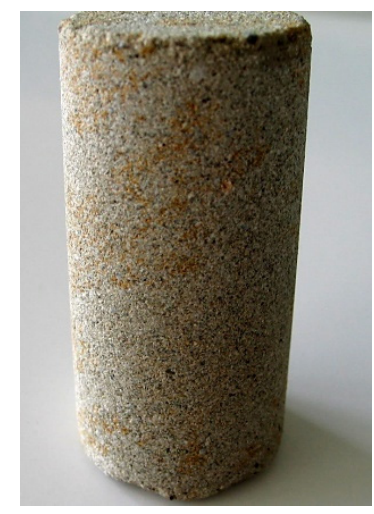

Figure 2. A core cut from a sandstone sample [27]. 


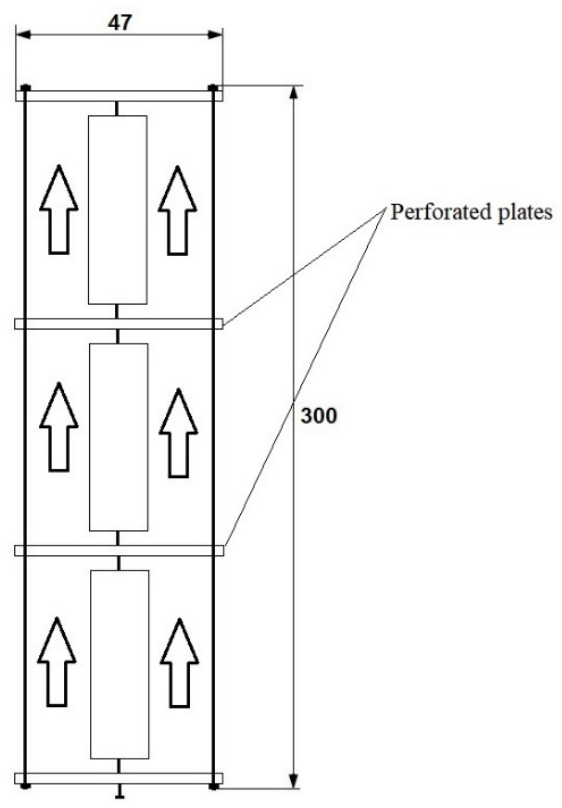

Figure 3. Arrangement of sandstone cores inside the plastic pipe [27].

In the first stage of the research, a mud cake was formed on the sandstone core. For this purpose, mud was pumped into the PVC pipe, which imitates the annular space of the borehole. The 3 cores were washed with the rinse for $1 \mathrm{~h}$. The mud flow rate was determined on the basis of previously performed preliminary tests and amounted to $4.5 \mathrm{~L} / \mathrm{min}$. The mud cake was made with a scrubber, the composition of which is given in Table 1. After preparation of the mud cake, the cores were washed with water for a period of 4, 6, 8, or $10 \mathrm{~min}$. In the tests, tap water was used as the standard wash liquid. After washing for the specified contact times, borehole preparation was assessed by testing the cement slurry adhesion to the core after it was cleaned. For this purpose, after forming a mud cake on the sandstone cores and then washing them with water for a specified period of time, the cores were covered with cement slurry (Figure 4). After a fixed setting time of $48 \mathrm{~h}$, an adhesion test was carried out on the contact between the hardened cement slurry and the sandstone core. The test was carried out in a testing machine. By measuring the applied load on the sample, the force required to break the adhesion was determined.

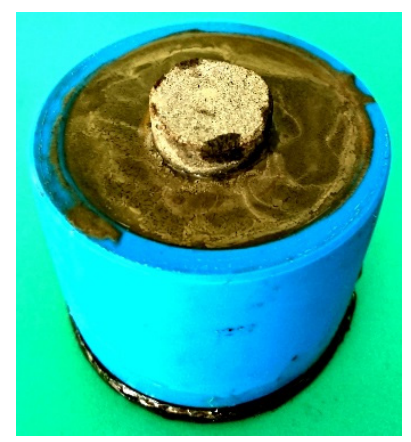

Figure 4. Sandstone core with cement slurry prepared for adhesion tests on the contact surface between the core and cement.

The adhesion expressed in MPa is calculated according to Equation (1) [27]:

$$
\sigma_{p}=\frac{\mathrm{P}}{\mathrm{s}} \cdot 10^{3}[\mathrm{MPa}]
$$

where $\sigma_{p}$ is adhesion at the point of contact between the bonded cement and the rock core (MPa), $\mathrm{P}$ is the force required to break the connection between the bonded cement 
and the rock core $(\mathrm{kN})$, and $\mathrm{s}$ is the contact area of the core with the cement slurry $\left(\mathrm{m}^{2}\right)$ Equations (2) and (3).

The testing machine monitor shows the pressure force $(\mathrm{P})$, and the outer surface area is derived from the circumference of the core and the height of the cement bound to the core. The dimensions needed for the calculations are shown in Figure 5 [27,28].

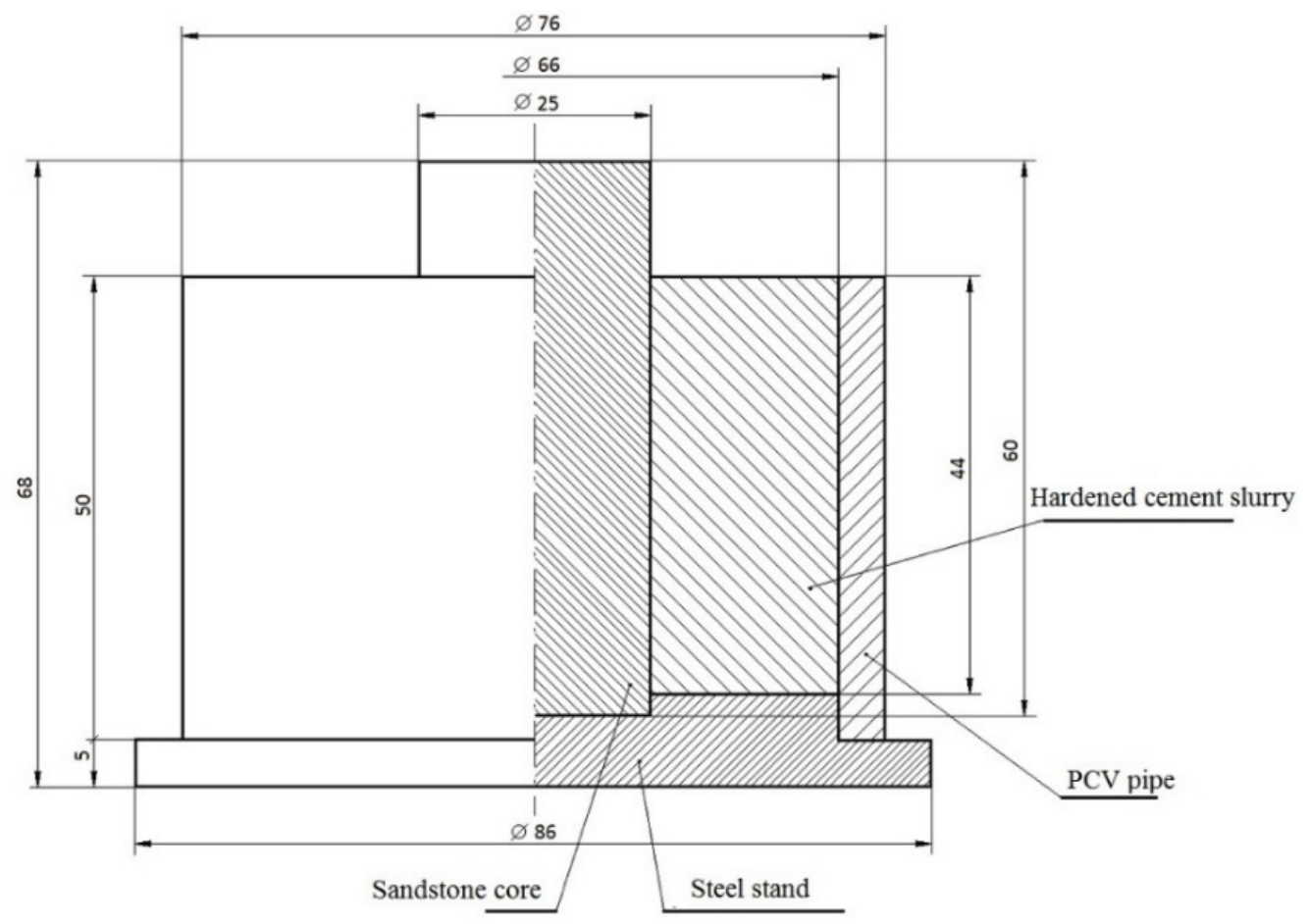

Figure 5. Diagram of a mold with a core and hardened cement slurry [27].

Explanation:

Core diameter $(\mathrm{d})=25 \mathrm{~mm}=0.025 \mathrm{~m}$, and the height of the cemented part of the core (h) $=44 \mathrm{~mm}=0.044 \mathrm{~m}$.

$$
\begin{gathered}
\mathrm{s}=\pi \times \mathrm{d} \times \mathrm{h} \\
\mathrm{s}=\pi \times 0.025 \times 0.044=0.003456\left[\mathrm{~m}^{2}\right]
\end{gathered}
$$

The adhesion of the bonded cement to the core is determined according to Equation (4):

$$
\sigma_{p}=\frac{\mathrm{P}}{3.456}[\mathrm{MPa}]
$$

It is also necessary to set benchmarks. For this purpose, adhesion measurements were taken for a "clean" core without a mud cake and for a core with a mud cake but without washing. The results in Table 3 are the maximum and minimum baseline adhesion. The obtained test results were compared to these values. Sandstone cores were flooded with a cement slurry of the same composition and parameters (Table 2).

Table 3. Baseline adhesion between hardened cement slurry and rock [27].

\begin{tabular}{lcc}
\hline & $\begin{array}{c}\text { The Force Required to Break } \\
\text { the Adhesion (N) }\end{array}$ & $\begin{array}{c}\text { Adhesion of Cement to the } \\
\text { Sandstone Core (MPa) }\end{array}$ \\
\hline Maximum control value & 8.2 & 2.37 \\
Minimum control value & 2.1 & 0.61 \\
\hline
\end{tabular}




\section{Results and Discussion}

The adhesion of the bonded cement to the cleaned rock core after the removal of the prepared mud cake ranged from 1.07 MPa to $1.77 \mathrm{MPa}$. Comparing these values with the minimum baseline adhesion of $0.61 \mathrm{MPa}$ reveals that the percentage increase in the adhesion value ranged from $75 \%$ (for 4 min of contact time) to $189 \%$ (for $10 \mathrm{~min}$ of wash contact), as shown in Table 4. These values are higher than those obtained using CEM I 32.5R class cement, which was tested in [27]. Comparing the obtained adhesion to the maximum baseline adhesion of $2.37 \mathrm{MPa}$ (Table 3) shows that the results ranged from $55 \%$ lower (contact time of $4 \mathrm{~min}$ ) to $26 \%$ lower (10 $\mathrm{min}$ of wash contact). Figure 6 shows a graphical summary of the results of the mud cake removal efficiency in terms of the contact time of the rinse compared to the maximum and minimum baseline values. This study supplements the work in [27]; in the previous study, another type of cement slurry based on CEM I 32.5R cement was used, and in this study, a cement slurry based on CEM I 42.5R cement was used.

Table 4. Adhesion between the bound cement and the rock for different wash contact times.

\begin{tabular}{|c|c|c|c|c|c|c|}
\hline Contact Time (min) & $2 \mathrm{~min}$ & $4 \mathrm{~min}$ & $6 \mathrm{~min}$ & $8 \mathrm{~min}$ & $10 \mathrm{~min}$ & $12 \mathrm{~min}$ \\
\hline Adhesion to the sandstone core (MPa) & & 1.07 & 1.51 & 1.62 & 1.77 & \\
\hline $\begin{array}{c}\text { Percentage change in the adhesion in } \\
\text { relation to the maximum baseline } \\
\text { adhesion (\%) }\end{array}$ & $-68 \% \pm 0.5 \%$ & $-55 \% \pm 0.5 \%$ & $-37 \% \pm 0.5 \%$ & $-32 \% \pm 0.5 \%$ & $-26 \% \pm 0.5 \%$ & $-24 \% \pm 0.5 \%$ \\
\hline $\begin{array}{l}\text { Percentage improvement in mud cake } \\
\text { removal efficiency }(\%)\end{array}$ & $+32 \% \pm 0.5 \%$ & $+45 \% \pm 0.5 \%$ & $+63 \% \pm 0.5 \%$ & $+68 \% \pm 0.5 \%$ & $+74 \% \pm 0.5 \%$ & $+76 \% \pm 0.5 \%$ \\
\hline $\begin{array}{c}\text { Percentage change in the adhesion } \\
\text { compared to the minimum baseline } \\
\text { adhesion (\%) }\end{array}$ & $+23 \% \pm 0.5 \%$ & $+75 \% \pm 0.5 \%$ & $+146 \% \pm 0.5 \%$ & $+165 \% \pm 0.5 \%$ & $+189 \% \pm 0.5 \%$ & $+195 \% \pm 0.5 \%$ \\
\hline
\end{tabular}

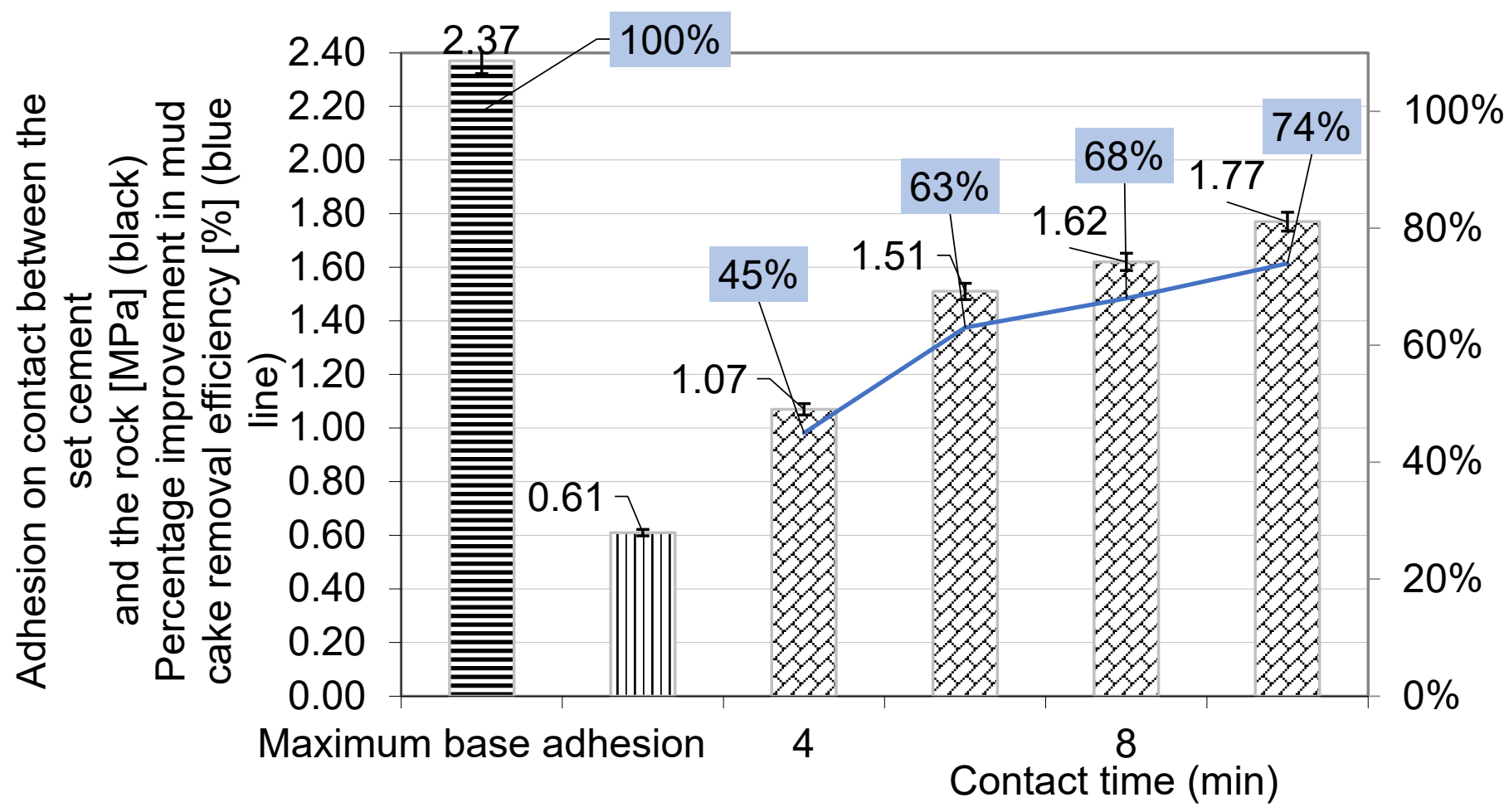

Figure 6. Values of adhesion of the hardened cement slurry to the core and the percentage improvement in mud cake removal (adhesion $2.37=100 \%$ mud cake removal). Results after different washing times.

In this study, an increase in the wash contact time was observed to increase the adhesion of the hardened cement slurry to the sandstone core. This results in an improvement 
in mud cake removal from the formation. The contact time of the wash strongly influences the efficiency of mud cake removal in the annular space. With the shortest contact time, which was $4 \mathrm{~min}$, the adhesion increased by $75 \%$. Extending the contact time of the wash by $2 \mathrm{~min}$ ( $6 \mathrm{~min}$ contact) increased the adhesion by another $71 \%$ compared to a wash contact time of $4 \mathrm{~min}$. The improvement over the baseline was $146 \%$ for a $6 \mathrm{~min}$ wash contact time. An adhesion value of $2.37 \mathrm{MPa}$ corresponds to $100 \%$ removal of the mud cake, as the core is clean, and the mud cake is eliminated. The core was only dipped in water to bring the measurement conditions closer to those of the core after rinsing. Based on the percentage reduction in adhesion compared to the maximum baseline value (2.37 $\mathrm{MPa})$, the percentage improvement in the cleaning efficiency of the annular space was obtained. Analysis of the results shows that the improvement in mud cake removal efficiency was $45 \%$ after $4 \mathrm{~min}$ of wash contact and $74 \%$ after $10 \mathrm{~min}$ of contact. Figures $7-10$ show the mud cake removal efficiency after different wash contact times.

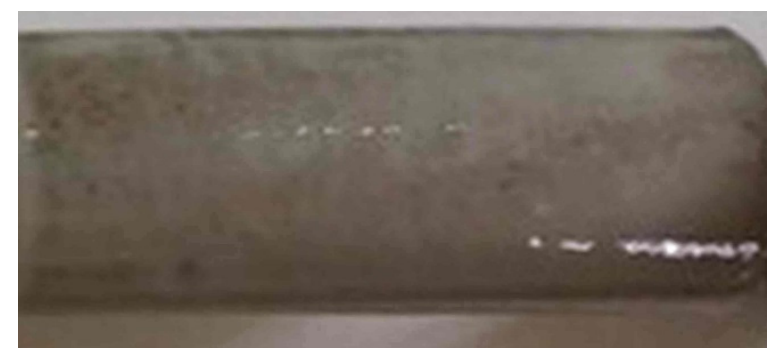

Figure 7. Wash contact time of $4 \mathrm{~min}$.

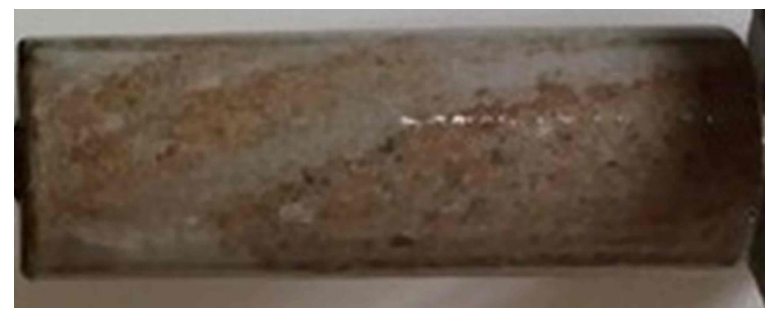

Figure 8. Wash contact time of $6 \mathrm{~min}$.

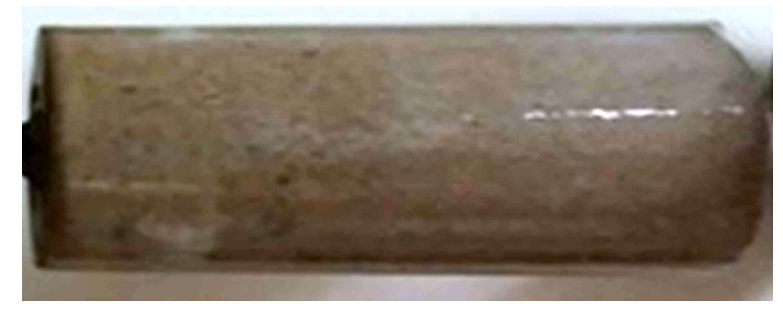

Figure 9. Wash contact time of $8 \mathrm{~min}$.

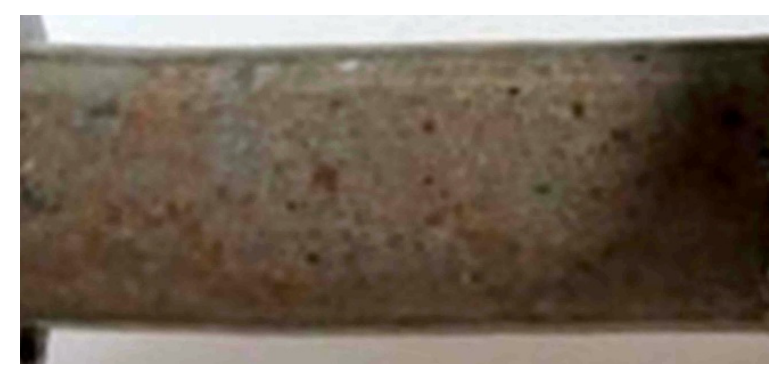

Figure 10. Wash contact time of $10 \mathrm{~min}$. 
When optimizing the obtained values, it is assumed that the best wash contact time is 6 min, which corresponds to a $63 \%$ mud cake removal efficiency. This wash contact time is optimal because if the wash is in contact with rock formations for a longer duration, it will remove weakly bonded structures. This $6 \mathrm{~min}$ time was considered the best on the basis of the adhesion value obtained only. This is the best value under laboratory conditions. However, bear in mind that the experiments optimize the contact time and do not allow for an assessment of the mechanical aspects. It is also important to choose a suitable wash composition. Then, the optimal contact time and wash flow rate allow for the efficient removal of the mud cake. This action contributes to the improvement of hole preparation by increasing the tightness of the contacts between the casing pipe, cement sheath, and borehole wall. The conducted research confirms the beneficial effect of an appropriate wash contact time on the preparation of the hole prior to cementing by increasing the efficiency of mud cake removal. This was observed for a mud cake made of polymer-potassium mud. Mud cakes are physicochemically diverse. The mud cake composition depends on the type of rock being drilled, the type and parameters of the mud, and borehole conditions. Therefore, each borehole should be considered individually. A considerable limitation in this type of research is the inability to generate bore pressure and liquid temperature in the borehole. However, despite these limitations, the tests carried out make it possible to determine to a very good degree the influence of the contact time of the washing liquid on the effectiveness of the washing mud cake removal.

\section{Conclusions}

1. On the basis of the obtained test results, the efficiency of mud cake removal largely depends on the wash contact time in the annular space.

2. The effectiveness of mud cake removal from a borehole is mainly determined by the type of flow, i.e., the amount of wash contact.

3. Although increasing the wash contact time improves the mud cake removal efficiency, it may damage the weakly compact zone; therefore, the required wash contact time and delivery rate for a given borehole must not be exceeded.

4. The tested wash contact times resulted in adhesion values ranging from $1.07 \mathrm{MPa}$ to 1.77 $\mathrm{MPa}$ (adhesion of the sample with the mud cake was $0.61 \mathrm{MPa}$, while the baseline sample without the mud cake had an adhesion of $2.37 \mathrm{MPa}$ ).

5. The obtained test results show that the adhesion improved by $75-189 \%$ relative to the minimum baseline value for a cement slurry based on class $\mathrm{G}$ drilling cement.

6. Comparing the obtained mud cake removal values to the maximum value of the baseline adhesion (removal of $100 \%$ of the mud cake), the improvement in the mud cake removal efficiency ranged from $45 \%$ after 4 min of wash contact to $74 \%$ after 10 min of wash contact.

7. The analysis of the obtained test results shows that the optimal wash contact time was $6 \mathrm{~min}$, which resulted in 63\% efficiency in removing the mud cake.

8. Tests on the effectiveness of mud cake removal under laboratory conditions do not completely replicate actual borehole conditions, but the constructed drilling fluid flow simulator allows borehole conditions to be reproduced to a large extent.

Author Contributions: Data curation, M.K. (Marcin Kremieniewski) and M.K. (Miłosz Kędzierski); investigation, M.K. (Marcin Kremieniewski); methodology, M.K. (Marcin Kremieniewski); writingoriginal draft, M.K. (Marcin Kremieniewski); project administration, M.K. (Miłosz Kędzierski); visualization, M.K. (Miłosz Kędzierski) and S.B.; resources, S.B.; supervision, S.B.; writing-review \& editing, S.B. All authors have read and agreed to the published version of the manuscript.

Funding: This work was financially supported by Ministry of Science and Higher Education Warsaw (Internal order Oil and Gas Institute-National Research Institute Project No. 58/KW/17 and 0015/KW/21).

Institutional Review Board Statement: Not applicable. 
Informed Consent Statement: Not applicable.

Data Availability Statement: Not applicable.

Acknowledgments: The authors thank the anonymous reviewers for their constructive comments and the editor for managing the paper.

Conflicts of Interest: The authors declare no conflict of interest.

\section{Nomenclature}

$\begin{array}{ll}\text { kN } & \text { Kilonewton } \\ \mathrm{MPa} & \text { Megapascal } \\ \mathrm{PCV} & \text { Polyvinyl chloride } \\ \mu \mathrm{m} & \text { Micrometer }\end{array}$

\section{References}

1. Błaż, S. Nowe rodzaje cieczy przemywających osady z płuczki inwersyjnej przed zabiegiem cementowania otworów wiertniczych. Nafta-Gaz 2017, 5, 302-311. [CrossRef]

2. Jasiński, B. Ocena wpływu cieczy przemywającej na jakość zacementowania rur w otworze wiertniczym po użyciu płuczki glikolowo-potasowej. Nafta-Gaz 2016, 6, 413-421. [CrossRef]

3. Adari, R.B.; Miska, S.; Kuru, E.; Bern, P.A.; Saasen, A. Selecting drilling fluid properties and flow rates for effective hole cleaning in high-angle and horizontal wells. In Proceedings of the Paper Presented at the SPE Annual Technical Conference and Exhibition, Dallas, TX, USA, 1-4 October 2000.

4. Zima, G. Wpływ właściwości płuczek wiertniczych na jakość cementowania w gazonośnych poziomach miocenu. Nafta-Gaz 2014, 12, 899-907.

5. Kremieniewski, M. Influence of Graphene Oxide on Rheological Parameters of Cement Slurries. Energies 2020, 13, 5441. [CrossRef]

6. Huang, S.; Feng, B.; Li, Z.; Tang, S.; Li, J.; Su, D.; Qi, L. Remediation of oil-based mud contaminated cement with talcum in shale gas well primary cementing: Mechanical properties, microstructure, and hydration. Constr. Build. Mater. 2021, $300,124047$. [CrossRef]

7. Zhang, F.; Miska, S.; Yu, M.; Ozbayoglu, E.; Takach, N.; Osgouei, R.E. Is well clean enough? A fast approach to estimate hole cleaning for directional drilling. In Proceedings of the Paper Presented at the SPE/ICoTA Coiled Tubing \& Well Intervention Conference \& Exhibition, The Woodlands, TX, USA, 24-25 March 2015.

8. Ahmed, A.; Mahmoud, A.A.; Elkatatny, S.; Chen, W. The effect of weighting materials on oil-well cement properties while drilling deep wells. Sustainability 2019, 11, 6776. [CrossRef]

9. Kremieniewski, M.; Rzepka, M. Przyczyny i Skutki Przeptywu Gazu w Zacementowanej Przestrzeni Pierścieniowej Otworu Wiertniczego Oraz Metody Zapobiegania Temu Zjawisku; Nafta-Gaz: Hünenber, Switzerland, 2016; p. 9.

10. Kmieć, M.; Karpiński, B.; Antoszkiewicz, M.; Szkodo, M. Laboratory research on the influence of swelling clay on the quality of borehole cementing and evaluation of clay-cutting wellbore tool prototype. Appl. Clay Sci. 2018, 164, 13-25. [CrossRef]

11. Kremieniewski, M. Ocena Skuteczności Oczyszczania Kolumny Rur Okładzinowych Przed Cementowaniem na Podstawie Badań Przy Użyciu Wiskozymetru Obrotowego; Nafta-Gaz: Hünenber, Switzerland, 2018; Volume 9, pp. 59-66.

12. Boyou, N.V.; Ismail, I.; Sulaiman, W.R.W.; Haddad, A.S.; Husein, N.; Hui, H.T.; Nadaraja, K. Experimental investigation of hole cleaning in directional drilling by using nano-enhanced water-based drilling fluids. J. Pet. Sci. Eng. 2019, 176, 220-231. [CrossRef]

13. Kremieniewski, M.; Kędzierski, M. Badanie Frakcjonowania Lekkich Materiałów Obniżajacych Gęstość Jako Wstępnego Parametru Podczas Projektowania Receptury Zaczynu Lekkiego; Nafta-Gaz: Hünenber, Switzerland, 2019; Volume 12, pp. $35-42$.

14. Saasen, A. Hole cleaning during deviated drilling-The effects of pump rate and rheology. In Proceedings of the Paper Presented at the European Petroleum Conference, The Hague, The Netherlands, 20-22 October 1998.

15. Yu, M.; Takach, N.; Nakamura, E.; David, R.; Shariff, M.M. An experimental study of hole cleaning under simulated downhole conditions. In Proceedings of the Paper Presented at the SPE Annual Technical Conference and Exhibition, Anaheim, CA, USA, 11-14 November 2007.

16. Wiśniowski, R.; Skrzypaszek, K.; Małachowski, T. Selection of a suitable rheological model for drilling fluid using applied numerical methods. Energies 2020, 13, 3192. [CrossRef]

17. Kremieniewski, M. Korelacja Skuteczności Działania Środków Dyspergujących o Różnym Mechanizmie Upłynniania; Nafta-Gaz: Hünenber, Switzerland, 2020; pp. 816-826.

18. Kateev, R.I. Casing of Wells in Abnormal Hydrodynamic Conditions of the Development of Oil Fields in Tatarstan; Nedra: Moscow, Russia, 2005; pp. 65-67.

19. Kremieniewski, M. Ultra-lightweight cement slurry to seal wellbore of poor wellbore stability. Energies 2020, 13, 3124. [CrossRef]

20. Ryan, D.F.; Browne, S.V.; Burnham, M.P. Mud clean-up in horizontal wells: A major joint industry study. In Proceedings of the Paper Presented at the SPE Annual Technical Conference and Exhibition, Dallas, TX, USA, 22-25 October 1995. 
21. Kremieniewski, M. Receptura zaczynu lekkiego do uszczelniania otworów w strefie niskich ciśnień złożowych. Nafta-Gaz 2020, 9, 577-584. [CrossRef]

22. Sifferman, T.; Becker, T. Hole Cleaning in Full-Scale Inclined Wellbores. SPE Drill. Eng. 1992, 7, 115-120. [CrossRef]

23. Saasen, A.; Løklingholm, G. The effect of drilling fluid rheological properties on hole cleaning. In Proceedings of the Paper Presented at the IADC/SPE Drilling Conference, Dallas, TX, USA, 11 February 2002.

24. Kremieniewski, M. Recipe of lightweight slurry with high early strength of the resultant cement sheath. Energies 2020, 13, 1583. [CrossRef]

25. Okrajni, S.; Azar, J. The Effects of Mud Rheology on Annular Hole Cleaning in Directional Wells. SPE Drill. Eng. 1986, 1, 297-308. [CrossRef]

26. Sanchez, R.A.; Azar, J.J.; Bassal, A.A.; Martins, A.L. The effect of drillpipe rotation on hole cleaning during directional well drilling. In Proceedings of the Paper Presented at the SPE/IADC Drilling Conference, Amsterdam, The Netherlands, 4-6 March 1997.

27. Li, Z.; Su, G.; Zheng, L. Enhancing filter cake removal by engineering parameter optimization for clean development of fossil hydrogen energy: A numerical simulation. Int. J. Hydrogen Energy 2021, 46, 12784-12800. [CrossRef]

28. Kremieniewski, M. Hybrid Washer Fluid for Primary Cementing. Energies 2021, 14, 1295. [CrossRef]

29. Kremieniewski, M. Badania środków poprawiających stabilność sedymentacyjną zaczynów cementowych. Nafta-Gaz 2020, 6 , 387-395. [CrossRef]

30. Hirpa, M.M.; Arnipally, S.K.; Kuru, E. Effect of the particle size on the near-wall turbulence characteristics of the polymer fluid flow and the critical velocity required for particle removal from the sand bed deposited in horizontal wells. Energies 2020, 13, 3172. [CrossRef]

31. Valluri, S.G.; Miska, S.; Yu, M.; Ahmed, R.M.; Takach, N. Experimental study of effective hole cleaning using sweeps in horizontal wellbores. In Proceedings of the Paper Presented at the SPE Annual Technical Conference and Exhibition, San Antonio, TX, USA, 24-27 September 2006.

32. Bilgesu, H.; Nekkhil, I.M.; Ameri, S. Understanding the effect of drilling parameters on hole cleaning in horizontal and deviated wellbores using computational fluid dynamics. In Proceedings of the Paper Presented at the Eastern Regional Meeting, Lexington, KY, USA, 17-19 October 2007.

33. Kremieniewski, M.; Kędzierski, M. Badania nad opracowaniem hybrydowej cieczy buforowej. Nafta-Gaz 2020, 76, 517-526. [CrossRef]

34. Zamora, M.; Jefferson, D.T.; Powell, J.W. Hole-cleaning study of polymer-based drilling fluids. In Proceedings of the Paper Presented at the SPE Annual Technical Conference and Exhibition, Houston, TX, USA, 3-6 October 1993.

35. Sayindla, S.; Lund, B.; Ytrehus, J.D.; Saasen, A. Hole-cleaning performance comparison of oil-based and water-based drilling fluids. J. Pet. Sci. Eng. 2017, 159, 49-57. [CrossRef]

36. Li, J.; Walker, S.A. Sensitivity Analysis of Hole Cleaning Parameters in Directional Wells. SPE J. 2001, 6, 356-363. [CrossRef]

37. Bizhani, M.; Corredor, F.E.R.; Kuru, E. Quantitative Evaluation of Critical Conditions Required for Effective Hole Cleaning in Coiled-Tubing Drilling of Horizontal Wells. SPE Drill. Complet. 2016, 31, 188-199. [CrossRef] 